\title{
Forgetting and Remembering in Post- dictatorial Argentina. Tiempo suspendido and the Ethics of Documentary Filmmaking Featuring People Living with Dementia
}

In countries in which dictatorial and repressive regimes were followed by democratic governments, what to remember and what to forget has been transformed into a master narrative with the conscious political aim of achieving the 'reconciliation' of the people. Spain and Argentina are two good examples of countries in which these questions have been actively debated regardless of the existence (Argentina) or absence (Spain) of a truth and reconciliation commission. Even when the atrocities of the repressive regimes were uncovered and acknowledged, exposing the erasure and silencing of those killed and missing remained and remains the focal point of the victims' families and supporters. Some victims' families perceived 'reconciliation' as a way of overlooking for a second time the terrible experiences of the missing persons (Lvovich and Bisquert 2008; Kriger and Guglielmo 2017). Therefore, voicing these experiences through the (re)construction and (re)telling of their (hi)stories before all traces of their past disappear is a common impulse for documentary filmmaking in these countries. The (re)telling and (re)construction of the past of the victims brings to the fore concepts such as, on the one hand, historical memory, remembering, collective and individual memory, and postmemory and, on the other hand, forgetting, memory loss and oblivion.

Alzheimer's disease, one of the most common forms of dementia, has been categorised as an epidemic by several international associations (e.g. Alzheimer's Disease International), and, as Lucy Burke (2015, 24) argues, it operates "as a form of cultural production in its own right." Forgetting and silence are two symptoms central to the experience of Alzheimer's, a disease whose name has been used in countries like Spain as metaphor to express collective historical forgetting (Medina 2013). Thus, forgetting the past in the era of Alzheimer's disease offers symbolic equivalence between collective/social memory and the experience of individual/personal memory, historical and subjective memory, and the need for postmemory. It is not surprising, then, that the trope of dementia as forgetting has increasingly emerged as a way to talk about both historical and subjective memories in cultural texts from countries in which repressive regimes 
were followed by democratic ones. ${ }^{1}$ Many of these documentary films have as their focal point or main characters people living with dementia because their old age and the nature of the disease bring to the fore the impending disappearance of the last living memories of traumatic events. However, this may be perceived as problematic, as it might make them vulnerable by displaying their traumatic experience or by exposing them to potentially unempathetic gazes. They are already vulnerable in social settings due to the disease; their vulnerability can be further increased in situations in which the filmmaker exerts their narrative power with the purpose of reconstructing a past that it is no longer remembered by the person living with dementia. The protagonists with dementia in most of these documentaries are parents or grandparents of the filmmakers, and they all suffered violence and were exposed to traumatic experiences during wars and dictatorships. Therefore, investigating the ethical or moral boundaries of producing documentary films with people with dementia will shed light on the ethics of representing collective/ national and individual trauma.

This essay aims to analyse the ethics of representation in Tiempo suspendido by Natalia Bruschtein, a documentary film in which she interviews her grandmother Laura Bonaparte, famous for being one of the co-founders of the movement Madres de la Plaza de Mayo (Mothers of the Plaza de Mayo), who is living with dementia. First, it contextualises Tiempo suspendido within current discussions around documentary film and its subgenres. Second, it studies the position that the filmmaker, the subject and the viewer take up in relation to the specific story told and to the processes of representation and identity construction. Third, Tiempo suspendido is analysed to unveil the different ways the viewer is required to understand the life of Laura Bonaparte and her identity, a subject that is at once national and personal. The use of photographs, public speeches and TV footage is examined alongside the interviews with the filmmaker's grandmother to show the mechanisms employed to construct a chronological concept of time that is nevertheless fragmented and full of gaps. Therefore, issues linked to the function of the different gazes in the documentary film are at the centre of attention. Finally, the focus of the discussion is a specific sequence as well as the editing of the film as a whole, with the goal of addressing the following questions: Can the triggering of memories related to a traumatic experience in a person living with dementia be justified when it serves to preserve the past or recover our own sense of identity as descendants? To what extent is it ethical to employ people

1 This is the case in several Spanish documentary films: Nedar, by Subirana (2008); Bucarest: La memoria perduda, by Solé (2008); and Cartas a María, by García Ribot (2014). 
living with dementia in film to illustrate 'cultural forgetting'? In this regard, issues such as voyeurism, vulnerability and consent will be discussed.

\section{Documentary film and the post-dictatorship generation in Argentina}

At the beginning of the twenty-first century, artistic expressions of the children of those who 'disappeared' during Argentina's military dictatorship (1976-1983) flourished. Even though these artists were not yet born or were too young to remember when their parents or family members disappeared, their work reveals the extent of the traumatic consequences of the atrocities committed by the military dictatorship on the present of personal and collective identity (Maguire 2017, 2). Autofictional narratives, testimonies, fictional and documentary films and plays are some of the forms these artistic expressions take in exploring intergenerational trauma. Since 2005, films and documentaries in which dementia is employed as a metaphor to explore either issues related to national identity, questions of gender in patriarchal societies or matters of historical memory have burgeoned across cultures (Medina 2018). In Argentina, Chile and Spain, to name just three countries, there have been many recent documentary films which attempt to recover the lost memories of people who were powerfully affected by traumatic events and the legacy of an oppressive regime and who today live with dementia. The concurrence between the increasing number of people living with dementia and the materialisation of a new type of documentary around the politics of memory seems to have influenced the manner in which dealing with the past and the obligation to remember it are understood. The horrors of the Spanish Civil War (1936-1939) and the subsequent Franco dictatorship (1939-1975), the Holocaust (1941-1945), la Dictadura Cívico-EclesiásticaMilitar in Argentina (1976-1983) and Pinochet's dictatorship in Chile (1973-1980) have been the subject of cultural texts and discussions linked, in one way or another, to 'dementia.' On the one hand, 'dementia' has been used as a medical excuse by defendants to avoid prosecution for crimes against humanity; on the other hand, it has been used to highlight the continuous and systematic forgetting of the historical past in the name of reconciliation. In many of these films the filmmaker is not only the narrator but also the child or grandchild of the person living with dementia who is at the centre of the film. Consequently, the journey charted in each is a journey of self-discovery and a quest for identity for the filmmaker. 
These films belong to what has been termed "performative documentary" (Bruzzi 2006), a genre which has been greatly influenced by the performativity of reality television and cinematic documentaries. The spectator of such a film realises that it is a negotiation between reality on the one hand and image, interpretation and bias on the other (Bruzzi 2006, 5-7). Similarly, Villarmea Álvarez (2014) notes that these documentaries combine visual materials from different sources, such as private home movies, archival footage and imaginary re-enactments, to covey "a 'subjective truth' that reveals the filmmaker's perception of historical events." Lastly, Jordana Blejmar (2016) notes that some subjective documentary films produced by the second generation have in common what Dubois (1995) called "mise-en-film"; that is, they exploit the fact that the ultimate understanding of the nature of a photograph depends on its interplay/contrast with other visual language. ${ }^{2}$ Overall, it is the performative and autobiographical dimensions of the new documentaries that make them function as allegories of the filmmakers' generational attitudes, country or time. This also applies to Tiempo suspendido. ${ }^{3}$

Laura Bonaparte was an Argentinian psychologist and human rights activist whose ex-husband as well as three of her children disappeared during the years 1976-1983. After having spent nine years exiled in Mexico, Bonaparte returned to Argentina in 1985 and, in 1986, co-founded the new strand of the Mothers of Plaza de Mayo, an organisation that fought to preserve the memory of the 30,000 desaparecidos - the disappeared - and aimed to bring the perpetrators to justice. In Tiempo suspendido (2015), Natalia Bruschtein presents a series of personal encounters with Laura Bonaparte, her grandmother, as well as Bonaparte's daily routine in the nursing home in which she resides. As Bruschtein has explained (Ranzan 2015), she started working on Tiempo suspendido in 2011, once her grandmother started experiencing memory loss. The filmmaker travelled to Argentina to learn more about Bonaparte's public and activist role by doing archival work and by interviewing her. According to Bruschtein, when the shooting of the documentary started, Bonaparte had already stopped recognising her, yet some kind of 'affective' connection remained, Bruschtein claimed, and therefore Bonaparte felt at ease with her during the filming. ${ }^{4}$

2 The 'second generation' is an expression used in countries such as Argentina to refer to the children of the desaparecidos.

3 The generational distance between postmemory, memory and history shapes this type of documentary film. Hirsch's (1997) concept of postmemory and Landsberg's (2004) of prosthetic memory explain the kind of recollection of past events deployed in subjective documentaries.

4 I sent an extensive questionnaire to Bruschtein, who kindly answered my questions at length. The translations of her responses are all mine. 
Bruschtein did not deliberately intend to use dementia as a metaphor about remembering a national past, but the stress placed on Bonaparte's human rights activism clearly brings to the fore her important social and political role in representing the political claims of those tortured and killed during the 'Dirty War.' The image of the activist who fought against oblivion and her more personal role as a woman who lost four family members are then unified in Tiempo suspendido. The documentary's structure reinforces these two sides in the figure of Bonaparte, as well as the granddaughter's quest: according to Bruschtein, she was trying "to recover the last thing that remains of a woman I have always admired and I think that it is fair that she is the one who remains in the memory of the viewer" (Medina 2019). The structure, then, presents a conception of time and temporality that positions the past as something reduced to physical traces - photographs, interviews, speeches, home films, TV images, official documents - in a present in which time has ceased to be chronological because of dementia. It is thus suspended. The granddaughter/filmmaker performs a threefold role, that of the historian who undertakes archival work and oral interviews to commemorate the public past of Bonaparte; that of the biographer of her grandmother's private past; and finally, that of autobiographer, since ultimately the quest is that of her own identity through the unveiling of her grandmother's personal past. In other words, the documentary's construction of layers of interactions and meanings allows the materialisation of the overall allegory of the filmmaker's generation, country and time: recovering a personal and collective/national traumatic past which is being forgotten but which still greatly affects the identity of many. As Susannah Radstone and Bill Schwarz $(2010,3)$ have stressed, in "collectively experienced catastrophes [. . .] the medium of memory has seemed to offer the possibility not only that an element of selfhood can be reconstituted, but also that a public, political language can be fashioned in which these experiences, and others like them, can be communicated to others."

\section{Tiempo suspendido's layers of memory and the concept of time}

Time in Tiempo suspendido is structured and constructed around three techniques which correspond to three chronological times: before the 'Dirty War,' after the 'Dirty War' and the time of filming and narrating. These three times are separated by many years, thus introducing not only the fragmentation of time but also the fragmented nature of the past and its effects on the physical and cognitive aspects of an individual. In addition, these three times are presented 
on screen in three different ways but always in the same diachronic sequence: the family pictures before the 'Dirty War'; TV footage, speeches, interviews and writings by Bonaparte during her years of political activism against the atrocities committed; and the present time of the narration in which the granddaughter interviews her grandmother. Noticeably, by assigning a different narrative medium to each moment in time and by arranging and editing them with the same structure, Bruschtein offers to the viewer multiple dimensions of time and memory.

The film itself is, as the title implies, a clear manifestation of the suspension of time as both interrupted/frozen and removed. In addition, the constant use of still images / photographs reminds us of Sontag's $(1977,5)$ thought that a "photograph passes for incontrovertible proof that a given thing happened. The picture may distort; but there is always a presumption that something exists, or did exist, which is what's in the picture." Photographs are ghostly presences of a past that no longer exists (Barthes 2000). For instance, the film encapsulates four notions of time which all depend on the character they are linked to, the person forgetting it or the person who wants to recover it: chronological time, the nostalgic notion of a former time, contrast between past and present, and time as a narrative construction. These four dimensions of time use images to reconstruct the common past. The still images of the time before the traumatic experience are followed by the moving images of Bonaparte's activist period, but both are contained within the overarching framework of the interviews and readings at the library in the present time of the narration. Still and moving images gain full personal meaning only if looked at by Bonaparte and the filmmaker; while public meaning is reached only by the viewer's gaze. In regard to the four dimensions of time, first, chronology is still present but it is full of gaps; for instance, most of those depicted in the photographs have been dead for many years and are also now disappearing from Bonaparte's memory; the present is full of absences, and absences shape the present. Second, the sequential use of photographs in storytelling develops a nostalgic notion of time which brings the impossibility of recuperation to the fore. Third, the contrast between Bonaparte's past and present is accentuated by the director's focus on her grandmother's declining cognitive and physical abilities. Finally, whereas the photographs, documents, speeches and TV footage serve the purpose of writing up the personal and public biography of Bonaparte as a counterpart to her memory loss, the interviews in which the granddaughter constantly corrects her grandmother's memories become the vehicle for forming Bruschtein's own identity/autobiography. 


\section{Gazing at Laura Bonaparte}

The film starts and ends at the National Library in Buenos Aires, thus emphasising the circularity of the story and the archives as the location in which memory is safely stored. This circularity highlights the fragility of human memory, that of the ill and ageing Laura Bonaparte in the present case, in contrast to the lasting memories archived in the library. Through the camera lens, the viewer is prompted to look at the past and present represented by the historical and personal figure of Bonaparte. However, the gaze of the viewer is always filtered through that of Bruschtein: the filmmaker reads documents, looks at pictures, interviews relatives and her grandmother; that is, she owns the authority of visual, oral and written discourse with which to present the fragility of human memory. Even though Bruschtein claims that this is not a film about her own identity, the filmmaker points out that in the case of Tiempo suspendido there were situations and issues that moved her emotionally. Therefore, it is important to stress that this emotional involvement at the autobiographical level influences both Bruschtein's and the audience's gazes. All the visual and written texts presented are mediated by the camera in the first instance, and then by Bruschtein's gaze at the camera, thus prompting the viewer to watch the film and assess the facts through her eyes.

Tiempo suspendido is shot over the span of three years in which Bonaparte and Bruschtein meet in different locations: the nursing home and family spaces. Bonaparte's dementia progression is reinforced not only by the time constrictions of the film but also by structuring the documentary as a sequence of the constant chronological contrasts of Bonaparte's life: the before of the disappearance of her family members; the time of her human rights activism against the atrocities committed in Argentina; and the Bonaparte at the time of the narration. The diachronicity of the film results from putting together synchronic moments that always follow the same pattern: before, after and now. The constant repetition of this pattern generates a strong contrast between the before and the now of Bonaparte that accentuates the void of her present. The focus of the camera on her memory loss and her bodily decay bolsters the notion of ageing and dementia as decline and loss of selfhood, and it also presents a nostalgic perception of the past (Swinnen 2013). The paradox created by bringing together in just one sequence conflicting meanings/conditions between the present of the filmmaker and Bonaparte, the photographic documents viewed by the filmmaker and audience, and the past writings of Bonaparte read by her granddaughter through voice-over, reinforces Bonaparte's experience of loss and grief in the past and Bruschtein's feelings of loss and grief in the present: "As we parents grow old, our children blossom” (00.02.44), the voice-over claims, while a picture of Bonaparte, her husband 
and their four young children on a beach occupies the totality of the frame for several seconds. The viewer is already aware of both the tragic events surrounding Bonaparte's life and her active role in demanding the truth about those disappeared; thus, it is the contrast offered on screen between Bonaparte as a public figure in the past and Bonaparte in the present of the nursing home that is accentuated. The opening shots that introduce Bonaparte at the time of the narration focus on her grey hair, wrinkled face and shaky, thin hands as well as on her inability to mark a number on her bingo card, using extreme close-up shots. The length of the shots gives the viewer the opportunity to look at this old woman for quite some time, with the camera concentrating on her aged body and vacant expression.

The space in which Bonaparte lives is presented in this introductory sequence as highly medicalised by opening the close-up and extreme close-up shots to a long shot in which a nurse and other older women in wheelchairs surround Bonaparte. This medicalisation is further strengthened in the following sequence which shows Bonaparte in her bed at the nursing home being woken up and served breakfast by a nurse. In contrast to a later scene, this scene shows in a sequence of close-ups of her face and wrinkled hands a joyful Bonaparte talking about her happy childhood. The viewer is placed in the position of the camera, thus not only bringing them into the room as if they were there with Bonaparte, but also as voyeurs who will watch the daily routine of this woman, her encounters with family members, her exchanges with her granddaughter and the progression of her disease. The viewer is constantly prompted to emotionally respond to what is shown. For example, in several instances there is a time discrepancy between pictures and memories recalled which underscores the disordered chronology of time in Bonaparte's memory. In some of these instances, Bonaparte remains cheerful and jokes about her poor memory. Her sense of humour serves as an empathic magnet for the viewer, who is this way predisposed to an emotional connection with the subject of their gaze.

It is precisely this empathy towards the subject that makes the scene that I will move on to analyse so shocking. It is the first time that grandmother and granddaughter are shown together on screen. The sequence alternates frames in which photographs occupy the full screen with close-up shots of Bonaparte and Bruschtein looking at photographs and talking about them, as well as medium shots that frame both women sitting at a table full of photographs. Each type of shot has a specific communicative function: photographs filling the screen function as both a means to talk about a past which no longer exists (Barthes 2000) and a way of making the viewer feel that they are in fact looking at the pictures as if they were inside the film; close-up shots that alternate photographs and the two people looking at them communicate to the viewer at the emotional level, immersing them in the action taking place and bringing them 
closer to both characters; and finally the medium shots push the viewer back out of the scene to emotionally distance them from what is about to happen with the intention of assigning them the role of witness. This movement from emotional involvement to distance ultimately transforms the viewer into a voyeur, gazing at the moment in which a traumatic event is recalled and in which they cannot intervene (Sontag 1977). The subject has become the object of knowledge in this precise moment, thus erasing the emotional bond between the filmmaker and her object of knowledge as previously established. This encounter between the subject and the filmmaker does not give access to subjectivity or to an ethical relation (Levinas 1993).

It is made clear in this sequence that Bonaparte is unable to put together names and faces in the photographs. Despite this, she keeps her sense of humour and remains cheerful until Bruschtein shows her a picture with three people and tells her grandmother that she "had kept this one for a long time because it is of your three missing children” (00.11:00-00.11:05). Bonaparte (Figure 1) suddenly remembers, and her face shows clear signs of surprise and distress. Bruschtein admits that she struggled emotionally with Bonaparte's reaction: "The moment that remained in the film is a moment that for me was also very strong, because at that moment I wasn't the director, but the granddaughter feeling a lot of pain because she did not remember her own children, my father" (Medina 2019). Notwithstanding Bruschtein's emotional involvement, the sequence withholds her reaction from the viewer. This is precisely the moment in which Bonaparte in fact remembers her traumatic experience. As a result, the viewer, who already is aware of Bonaparte's memory loss, is positioned to watch her traumatised reaction. The whole sequence focuses on Bonaparte's private life, not on her public profile, thus making the viewer empathise with her at the personal/emotional level. Likewise, once the identification with Bonaparte is established and her vulnerability is brought to the fore, the scene becomes difficult to watch. Immediately after, the viewer is forced to move away from the scene to the position of the voyeur, which does not allow them to protect the vulnerable subject but just to observe.

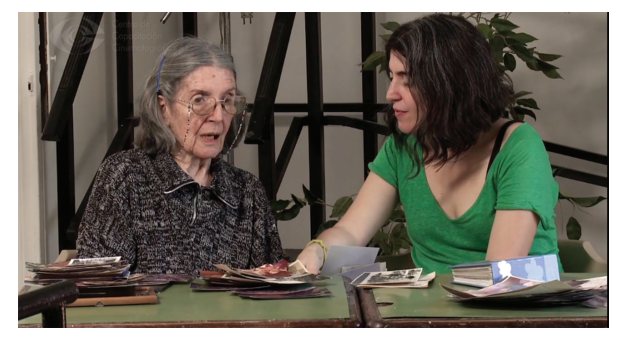

Figure 1: The viewer as voyeur: Watching Bonaparte's reaction to the photograph. 
Time after time viewers are impelled to witness this painful recollection of the past. Moreover, what the film makes visible as well through this insistence on making Bonaparte remember is that memory loss is presented as a loss of selfhood. The constant questioning by Bruschtein that Bonaparte has to undergo throughout the documentary makes memory the key factor in personhood, thus reinforcing the idea commonly found in hegemonic social and cultural discourses that the mind constitutes the base of personhood. Bruschtein, in her attempt to document the paradoxical nature of memory personified in the private and public figure of Bonaparte, places memory as the key factor of being, thus dispossessing her grandmother of personhood. For instance, just after this sequence the film moves from the shot of Bruschtein's hand holding the same photograph to footage in slow motion of her during her years as a human rights activist. If taken together, these two mirroring scenes present what is absent: individual memory. Hence, memory is charged from this point onwards as a marker for personhood and identity.

The Cartesian body/mind dualism has linked identity to the mind. Dementia's cognitive impairment would then mean that an individual with dementia is no longer a person (Brody 2003). From this perspective, the loss of memory implies a loss of reasoning and of the ability to communicate through language, which would reduce the subject's capacity to have meaningful social interactions (Cohen and Eisdorfer 1986). ${ }^{5}$ Tiempo suspendido presents a person living with dementia who interacts with family members and caregivers inside and outside the nursing home. However, these interactions always seek to make Bonaparte remember the past by questioning her or emphasise her memory loss. Not surprisingly then, memory loss and questions about her missing children are presented in an almost identical manner throughout the film. For example, in 00.33.10 she is asked by Bruschtein if she remembers why she left Argentina to live in Mexico, to which Bonaparte responds: “No, I don't remember.” A close-up shot then emphasises Bonaparte's vacant expression, confirming her answer as truthful (Figure 2).

One hour into the film, Bonaparte asks Bruschtein, "Victor did not go missing, did he?," thus accentuating once more Bonaparte's memory loss and suffering. Yet again, and with a close-up shot, the viewer witnesses shock (Figure 3) and pain on Bonaparte's face. This is followed by Bonaparte's words, "Well, memory, after all, is not a bad thing to lose" and her evaluation of life as an adventure. The

5 A radically different perspective is offered by those who consider the important role social interactions have in preserving a sense of selfhood in people with dementia (Kitwood 1993; Sabat and Harré 1992). 


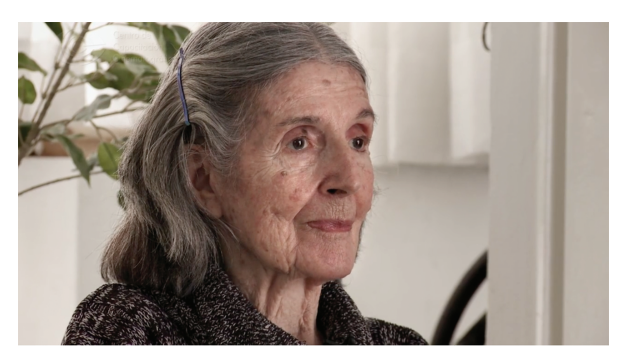

Figure 2: A close-up shot confirming Bonaparte’s gaps in memory.

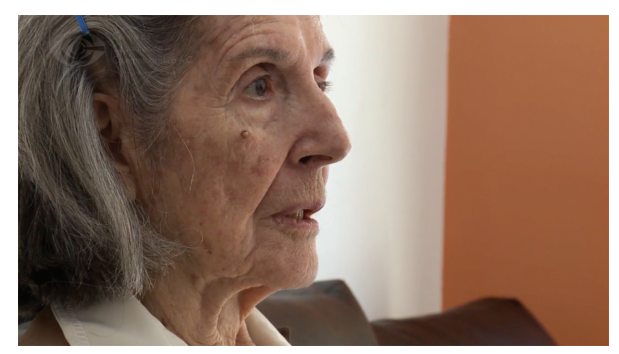

Figure 3: "Well, memory, after all, is not a bad thing to lose".

words of the 86-year-old Bonaparte are immediately eclipsed by an excerpt from her earlier writings, read by Bruschtein: "When I die, my missing children will die with me, as will the memory of their birth and their upbringing; and that is a great sorrow" (1:02:31-1:02:39).

The audience is confronted by the paradoxical nature of memory when dementia meets history and politics. As much as Bruschtein could be searching for personal memories of her father ${ }^{6}$ or aiming to preserve the experience of her grandmother as a public and private figure, the way in which these truths are presented on screen is solely linked to Bonaparte as a public figure. That is, since personal memories are absent, the memories presented correspond to her public profile as a human rights activist. This constant conflict offered on screen between the past active and coherent public figure and the present cognitively impaired private subject makes the viewer focus on memory loss as the loss of communicative memory (Assmann 2008): autobiographical memories which can

6 Recovering memories about her father was the main purpose of Bruschtein's film Encontrando a Víctor (2005). 
no longer be communicated and their transformation, in the case of a public figure, into cultural memories.

\section{Working on screen with people living with dementia - a question of ethics}

The sequences just analysed bring out some crucial issues in working with people with dementia. Recovering the past from people living with dementia can make them even more vulnerable as they relive their traumatic experience. There have been plenty of scholarly discussions around the ethics of documentary film and ethical responsibilities of filmmakers (Katz and Katz 1988; Aibel 2003; Butchard 2006; Maccarone 2010; Nash 2011). Among the most important are issues, consent, disclosure and motive. When dealing with autobiographical documentary films, the intimacy permeating these films makes it difficult to ponder whether in certain circumstances the filmmaker is pushing ethical boundaries (Katz and Katz 1988; Swinnen 2013). Bruschtein, in this sense, recognises in her interview with me that intimacy and familiarity made things easier. Likewise, she acknowledges that she sought permission from her uncle, the only surviving son, and cousins before she started filming. Bruschtein explains that shooting with her grandmother was simple, and Bonaparte was very happy (Medina 2019).

Regardless of whether consent was obtained or the motive disclosed to Bonaparte before or during the filmmaking process, Bonaparte is pressed to involuntarily reexperience a traumatic event, thus causing her harm, even if only momentarily. The structure of all the sequences in which she is shown photographs of her missing children stresses Bonaparte's memory loss. However, instead of stopping her push to remember, Bruschtein not only corrects her in all instances by naming those in the picture but also tells her that they all went missing. Consequently, there is clear evidence of harm that is repetitious in nature and is indeed enabled by the intimacy between them. That is, one would expect intimacy to prevent harm instead of facilitating it and to emphasise the positive elements of both dementia and ageing instead of its deficits. However, in the film, Bonaparte's vulnerability is openly displayed and results in charging her, as I see it, with the weight of forgetting both the individual and collective past. The viewer's admiration for the public figure evolves to compassion and sadness but additionally evacuates the private Bonaparte of personhood. Early in the film the focus turns out to be the present decline of the public figure of Bonaparte. Even if Bruschtein never intended this to be the case, the 
continuous contrasts displayed on screen between her past and the present realities inevitably foreground her physical and cognitive impairment.

Ageing and dementia are presented unquestionably as decline. On the one hand, Bonaparte's memory loss means that Bruschtein's quest is still incomplete at the end of the film as her efforts to recover memories about her father fail. On the other hand, the absence of memory forces the camera to shift to presenting Bonaparte's body, mainly hands and face, in close-up shots that capture in detail her aged body (Figure 4) in persistent contrast to her younger one. Bonaparte's aged body converts her into a 'living' photograph, present but unable to provide information beyond her own image. The reification of the body is stressed by the similarity between the wrinkled and veined hands and the patterns of the bed cover, whereas the shaking hands hidden under the table function as signs of ageing as illness and decline towards death. Like photographs, Bonaparte's body is presented as the site where time is suspended, or in Barthes's (2000) terms, the space in which to gaze at the return of the dead. ${ }^{7}$

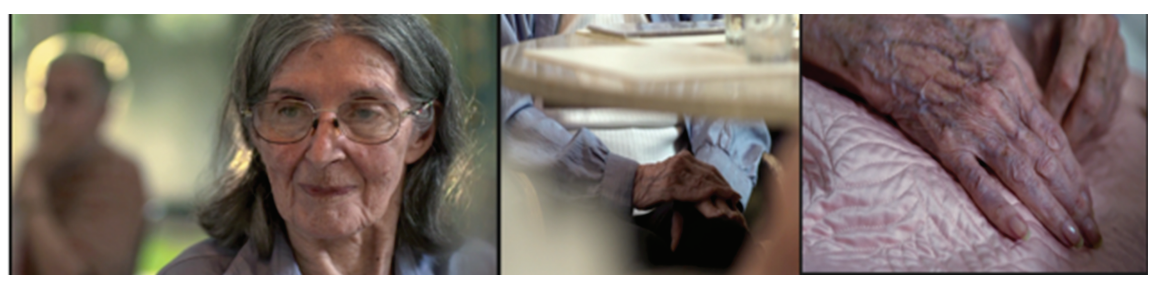

Figure 4: The camera's focus on Bonaparte's aged body.

\section{Conclusion}

The three layers of memory illustrate its fragmented and synchronic quality and thus reinforce the suspension of time. If time is understood as movement from the past to the present towards a future, in the film time is suspended in two ways: first, time is static; and second, time has ceased to be time. In both cases what results is the absence of a future. The contrast between past and present creates a nostalgic perception of the past and accentuates the present as painful and full of silences. However, in Tiempo suspendido the person living with dementia is not someone whose past needs to be recovered because it is unknown. We know everything there is to know about Laura Bonaparte as a public and

7 Derrida's (2006) notion of spectre could be employed here as analytical tool as well. 
activist figure, and recovering the past of Victor Bruschtein was already the focus of Encontrando a Victor. Additionally, in Tiempo suspendido the person living with dementia is placed on screen as a site of memory, and on her rests all the weight of family and national memory.

The viewer is positioned to gaze at Bonaparte from different angles and spaces with the intention of emotionally communicating the paradoxical nature of memory. However, the viewer's intended voyeurism when situated outside the story is in fact reversed by the distress that Bruschtein causes to both her grandmother and the viewer when revealing the death of Bonaparte's children. It is not an act of forgetting that the viewer witnesses but the pain of a particularly vulnerable person remembering a traumatic event. Even if completely unintentionally, the centrality of this vulnerability and harm dominates the documentary film and unquestionably raises issues around pushing ethical boundaries when people living with dementia are placed in front of the camera. Finally, the conception of selfhood as the dualism of body/mind and the suspension of time associated with Bonaparte's aged body transforms Bonaparte into a 'living' photograph unable to provide information beyond her own image.

\section{References}

Aibel, Robert. "Ethics and Professionalism in Documentary Film-Making." Ed. Larry Gross, John Stuart Katz and Jay Ruby. Image Ethics: The Moral Rights of Subjects in Photographs, Film, and Television. New York: Oxford UP, 1988. 108-118.

Assmann, Jan. "Communicative and Cultural Memory." Ed. Astrid Erll, Ansgar Nünning.

Cultural Memory Studies. Berlin: De Gruyter, 2008. 109-118.

Barthes, Roland. Camera Lucida. Trans. Richard Howard. London: Vintage, 2000.

Blejmar, Jordana. "Imagen-momia e imagen-ruina: La mise-en-film de las fotografías de los desaparecidos en el documental subjetivo de la posdictadura Argentina." Kamchatka: Revista de Análisis Cultural 8 (2016): 255-273.

Brody, Howard. Stories of Sickness. New York: Oxford UP, 2003 [1988].

Bruzzi, Stella. New Documentary. New York: Routledge, 2006.

Burke, Lucy. "The Locus of Our Dis-ease: Narratives of Family Life in the Age of Alzheimer's." Ed. Aagje Swinnen and Mark Schweda. Popularizing Dementia: Public Expressions and Representations of Forgetfulness. Bielefeld: Transcript, 2015.

Butchart, Garnet C. “On Ethics and Documentary: A Real and Actual Truth." Communication Theory 16 (2006): 427-452.

Cohen, Donna, and Carl Eisdorfer. The Loss of Self. New York: W. W. Norton, 1986.

Derrida, Jacques. Spectres of Marx: The State of the Debt, the Work of Mourning and the New International. New York: Routledge, 2006. 
Dubois, Philippe. "Photography Mise-en-Film. Autobiographical (Hi)stories and Psychic Apparatuses.” Ed. Patrice Petro. Fugitive Images: From Photography to Video. Bloomington: Indiana UP, 1995. 152-172.

Hirsch, Marianne. Family Frames: Photography, Narrative, and Postmemory. Cambridge, MA: Harvard UP, 1997.

Katz, John Stuart, and Judith Katz. "Ethics and the Perception of Ethics in Autobiographical Film.” Ed. Larry Gross, John Stuart Katz and Jay Ruby. Image Ethics: The Moral Rights of Subjects in Photographs, Film, and Television. New York: Oxford UP, 1988: 119-130.

Kitwood, Tom. "Towards a Theory of Dementia Care: The Interpersonal Process." Ageing and Society 13.1 (1993): 51-67.

Kriger, Miriam Elizabeth, and Luciana Cecilia Guglielmo. "Memorias sociales y familiares de la dictadura cívico-militar: Narrativas biográficas de integrantes de la asociación Abuelas de Plaza de Mayo.” Revista Colombiana de Sociología 40.1 (2017): 45-63.

Landsberg, Alison. Prosthetic Memory: The Transformation of American Remembrance in the Age of Mass Culture. New York: Columbia UP, 2004.

Levinas, Emmanuel. Outside the Subject. New York: Athlon Press, 1993.

Lvovich, Daniel and Jorgelina Bisquert. La cambiante memoria de la dictadura. Discursos sociales y legitimidad democrática. Buenos Aires: Biblioteca Nacional-UNGS, 2008.

Maccarone, Ellen M. "Ethical Responsibilities to Subjects and Documentary Filmmaking." Journal of Mass Media Ethics 25.3 (2010): 192-206.

Maguire, Geoffrey. The Politics of Postmemory: Violence and Victimhood in Contemporary Argentine Culture. Basingstoke: Palgrave Macmillan, 2017.

Medina, Raquel. “Alzheimer's Disease, a Shifting Paradigm in Spanish Film: ¿Y tú quién eres? and Amanecer de un sueño." Hispanic Research Journal 14.4 (2013): 356-372.

Medina, Raquel. Cinematographic Representations of Alzheimer's Disease. Basingstoke: Palgrave Macmillan, 2018.

Medina, Raquel. Interview with Natalia Bruschtein. Gynocine Project. https://www.gynocine. com/interview-natalia-bruschtein, 2019 (17 September 2020).

Nash. Kate. "Documentary-for-the-Other: Relationships, Ethics and (Observational) Documentary." Journal of Mass Media Ethics 26.3 (2011): 224-239.

Nichols, Bill. Introduction to Documentary. Bloomington: Indiana UP, 2001.

Radstone, Susannah, and Bill Schwarz. "Introduction. Mapping Memory." Ed. Susannah Radstone and Bill Schwarz. Memory: Histories, Theories, Debates. New York: Fordham UP, 2010. 1-9.

Ranzan, Oscar. "Natalia Bruschtein presenta su documental Tiempo Suspendido, hoy en el Incaa km 0 Gaumont.” 13 November 2015, https://www.pagina12.com.ar/diario/suple mentos/espectaculos/5-37209-2015-11-13.html (10 September 2019).

Sabat, Steve, and Rom Harré. "The Construction and Deconstruction of Self in Alzheimer's Disease." Ageing and Society 12.3 (1992): 443-461.

Sontag, Susan. On Photography. New York: Penguin, 1977.

Swinnen, Aagje. "Dementia in Documentary Film: Mum by Adelheid Roosen." Gerontologist 53.1 (2013): 113-122.

Villarmea Álvarez, Iván. "Cinema as Testimony and Discourse for History: Film Cityscapes in Autobiographical Documentaries.” Revue LISA/LISA e-journal XII.1 (2014). https://doi. org/10.4000/lisa.5579 (29 January 2020). 


\section{Filmography}

Bucarest: La memoria perduda. Dir. Albert Solé. Bausan Films, 2008.

Cartas a María. Dir. Marta García Ribot. Pages \& Images, 2015.

Encontrando a Víctor. Dir. Natalia Bruschtein. Centro de Capacitación Cinematográfica, 2005.

Nedar. Dir. Carla Subirana. Benecé Produccions, 2008.

Tiempo suspendido. Dir. Natalia Bruschtein. Centro de Capacitación Cinematográfica, 2015. 